\title{
FERTILITY AND SPERM TRANSPORT IN MERINO EWES AT THE FIRST OESTRUS FOLLOWING EMBRYONIC DEATH
}

\author{
T. N. EDEY,* G. J. THWAITES, ${ }^{*}$ F. A. PIGOTT* AND \\ T. O'SHEA $\dagger$ \\ Departments of ${ }^{*}$ Livestock Production and $\uparrow$ Physiology, \\ University of New England, Armidale, New South Wales 2351, Australia
}

(Received 29th October 1974)

\begin{abstract}
Summary. The embryos of ewes were killed with colchicine on Day 17 of gestation and the ewes were mated at the subsequent oestrus. Fertility was reduced at this mating, and fewer spermatozoa were found in the uterus and oviducts than in control animals. The total number of spermatozoa in the cervix and their distribution between the lumen and walls of the cervix were not altered, but the linear distribution along the cervical walls was changed. The density of the remaining spermatozoa in the control animals after flushing of the cervix showed a progressive decrease from the posterior to the anterior segments. This did not occur in the untreated ewes. It seems likely that impaired sperm transport contributed to the lowered fertility.
\end{abstract}

\section{INTRODUGTION}

Delayed returns to service have been reported in Merino ewes experiencing embryonic death after the initiation of the CL of pregnancy (Edey, 1967), and affected ewes exhibited subnormal fertility when mated at the first oestrus after embryonic death (Edey, 1970, 1972). At present, however, little is known of the cause of this reduced fertility. In a study of resorption following embryonic death at known times after mating, Thwaites (1972) observed that the caruncles (cotyledons) of ewes returning to service were unusually large and haemorrhagic and that their uteri appeared to contain unusually large leucocyte populations. These conditions could interfere with normal sperm transport and ovum development, and the present work was undertaken to investigate these possibilities.

\section{MATERIALS AND METHODS}

\section{Animals and treatments}

Ewes were fed at maintenance level on pasture supplemented with lucerne hay. Their mean live-weight was assessed by fortnightly weighings, and remained virtually constant at $36 \mathrm{~kg}$ throughout the experiment. Oestrus (raddle marks) was detected twice daily ( 09.00 and 17.00 hours) at critical stages of the experiment, and once daily (09.00 hours) at other times. 
During the autumn of 1971 , oestrus was synchronized by means of progestagen-impregnated vaginal sponges in a randomly selected group of seventy-four mature Merino ewes. After the first synchronized oestrus, the ewes were randomly allocated to one of two groups, each of which was subsequently split again to give four groups.

To form Groups 1 and 2, forty-two ewes were run with raddled entire rams to permit fertile service at the second oestrus after synchronization. Seventeen days thereafter, ewes which had been mated and had not already returned to service were subjected to mid-ventral laparotomy (Lamond, 1963), and ewes with a single apparently functional CL received an injection of $2 \mathrm{mg}$ colchicine in $0.2 \mathrm{ml}$ distilled water into the lumen of the ipsilateral uterine horn. Ewes with bilateral apparently functional CL received an injection of $1.5 \mathrm{mg}$ colchicine into the lumen of each uterine horn. Previous work (Edey, 1967) had shown that these treatments rapidly killed the embryo without any apparent effect on the dam. Twenty-one presumably pregnant ewes received the colchicine treatment and were then kept with vasectomized rams until return to service, at which time they were hand-mated to two fertile rams and allocated either to Group 1 or Group 2. Four ewes became anoestrous after colchicine treatment so that finally nine were allocated to Group 1 and eight to Group 2. The ewes in Group 1 were killed $16 \mathrm{hr}$ after coitus by an intravenous injection of $20 \mathrm{ml}$ sodium pentobarbitone and were used for the recovery of spermatozoa (see below). Pregnancy was allowed to proceed in the ewes of Group 2; returns to service were recorded, a pregnancy test was performed (Lamond, 1963) at about Day 50, and lambing data were obtained.

The remaining thirty-two ewes were kept with raddled vasectomized rams until the third cycle after synchronization when those exhibiting oestrus were randomly allocated to two groups, nine ewes to Group 3 and sixteen to Group 4. The ewes of Group 3 were killed $16 \mathrm{hr}$ after being hand-mated to the two fertile rams and were used for the recovery of spermatozoa, acting as controls for Group 1. The ewes of Group 4 provided fertility data after the use of colchicine in the non-pregnant tract. On Day 4 following the third oestrus, they were injected with colchicine as for Group 2, and the twelve ewes which subsequently returned to service were re-mated to fertile rams. Their fertility was monitored as for Group 2. The experimental design is summarized in Text-fig. 1.

\section{Determination of numbers of spermatozoa in the lumen of the genital tract}

After mating, the ewes were left undisturbed until they were killed by rapid intravenous injection of an overdose of sodium pentobarbitone $16 \mathrm{hr}$ after coitus. Following death, the abdominal and pelvic cavities were immediately opened and the genital tract was ligated at the base of the oviducts, the base of the uterine body, the distal end of the cervix, and at the junction of the urethra with the vagina. After removal to the laboratory, the tract was divided into five segments; the two oviducts, the uterus, the cervix and the anterior vagina.

The tubes were flushed from the ovarian end with $1.5 \mathrm{ml}$ of $0.9 \%$ warm saline in three aliquots, following each of which $0.5 \mathrm{ml}$ air was forced through the lumen (Murdoch \& O'Shea, 1973). Both the uterus and cervix were flushed 


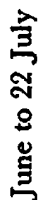
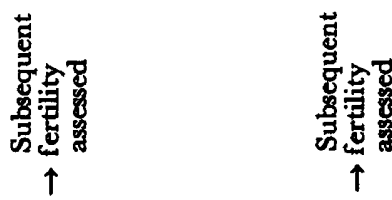

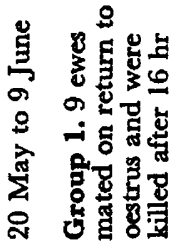

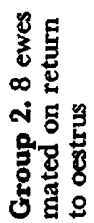

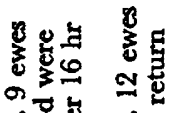

m.
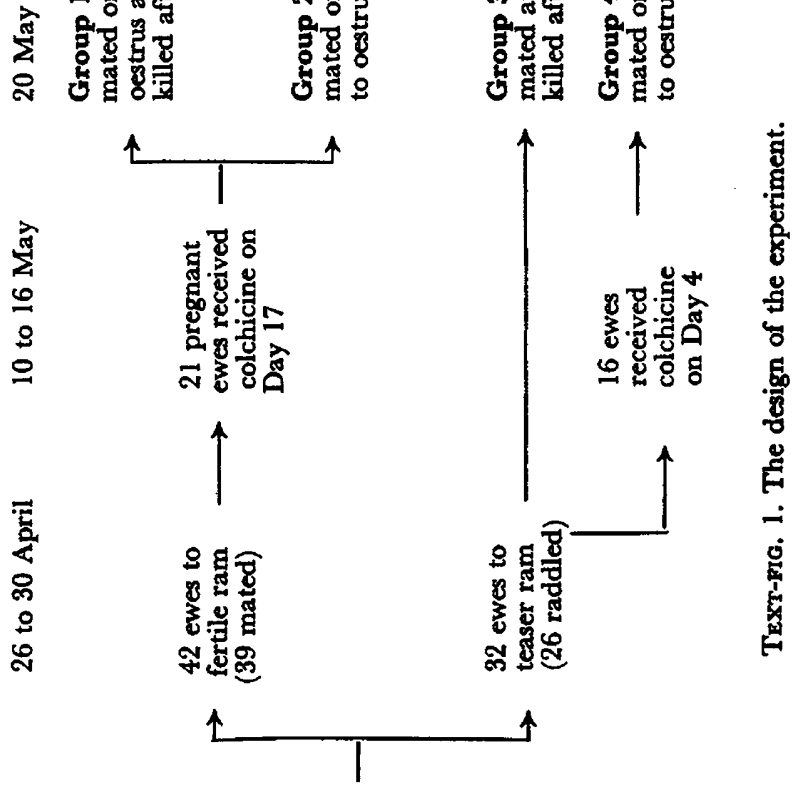

$\sum^{\pi}$
0
0
0

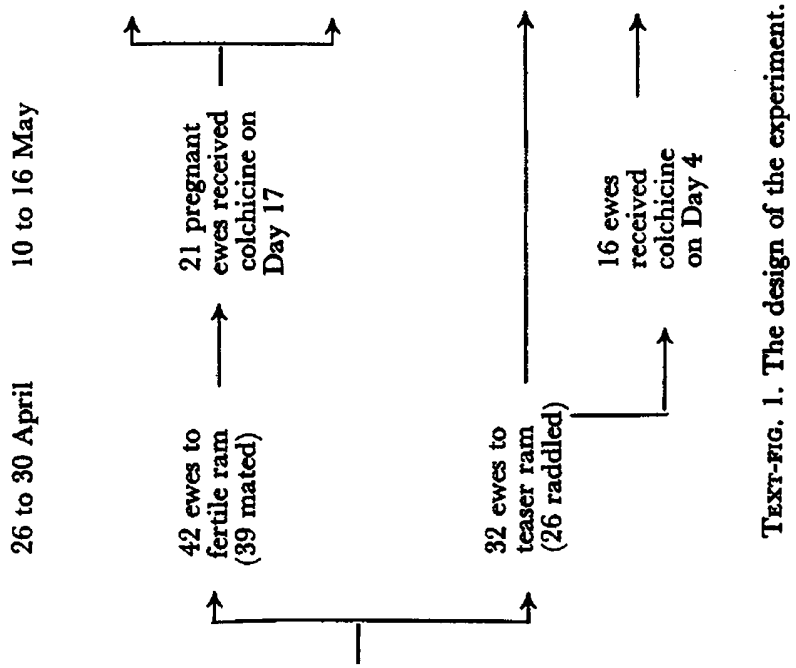

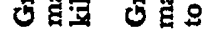

3
0
0
0
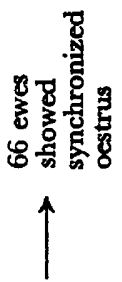

స్

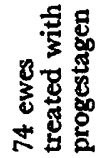


with $5 \mathrm{ml}$ saline in two aliquots; each flushing being followed by $2.5 \mathrm{ml}$ air. After the anterior vagina was flushed with approximately $5 \mathrm{ml}$ saline, it was cut open and washed with a further $5 \mathrm{ml}$. A drop of formalin was added to the washings to immobilize the spermatozoa, and if any mucus was present it was dispersed by adding a small amount of hypochlorite solution. When spermatozoa were not counted immediately, the samples were stored at $-15^{\circ} \mathrm{C}$.

Samples of the washings were placed in a Fuch-Rosenthal counting chamber of depth $0.2 \mathrm{~mm}$ and, after allowing $5 \mathrm{~min}$ for the spermatozoa to settle, the number of spermatozoa in each chamber was counted. The total number of spermatozoa in the washings was then calculated. Counts were based on four chambers if there were thirty or more spermatozoa per chamber, and on ten chambers when there were fewer spermatozoa. A normal haemocytometer was used when the sample contained too many cells to be counted in a FuchsRosenthal chamber.

Throughout the experiment, care was taken to avoid cross-contamination by using different instruments when handling different segments of the tract, and by using siliconized glassware and new plastic syringes.

Following flushing, the cervices were fixed in formol-saline. After the length of the fixed organ had been recorded, $1-\mathrm{cm}$ portions from the anterior, middle, and posterior regions of the cervices were taken. Ten complete cross-sections cut at $5 \mu \mathrm{m}$ were taken along each block, and the sperm heads present were counted. The counts were corrected for error arising out of the interaction between thickness of section and nuclear size by applying Abercrombie's formula (Abercrombie, 1946; Mattner, 1968).

For statistical analysis, the values obtained (plus 2 to deal with zero values) were transformed on the $\log _{10}$ scale to give homogeneous variability.

\section{Uterine histology}

Following flushing, segments $1 \mathrm{~cm}$ long from both ends of both uterine horns, were preserved in formol saline for later histological study. Sections of these, cut at $8 \mu \mathrm{m}$ and stained with haematoxylin and eosin, were studied on the projection microscope. Epithelial thickness was estimated from a series of ten randomly selected sites in each section, and the number of endometrial glands transecting ten randomly selected radii, $500 \mu \mathrm{m}$ in length, was recorded. Tracings were made of each projected section and from these the areas of the lumen, endometrium and circular muscle layer were estimated by means of a compensating planimeter.

\section{RESULTS}

\section{Fertility}

When the ewes of Group 2 were re-mated after the embryos present in their uteri were killed on Day 17, the pregnancy rate at Day 50 following re-mating (one pregnant of eight mated) was significantly lower $\left(\chi_{1}^{2}=4.2 ; P<0.05\right)$ than in the Group-4 ewes (seven pregnant of twelve mated) for which re-mating took place at the next oestrus after administration of colchicine on Day 4 of the previous oestrous cycle. 


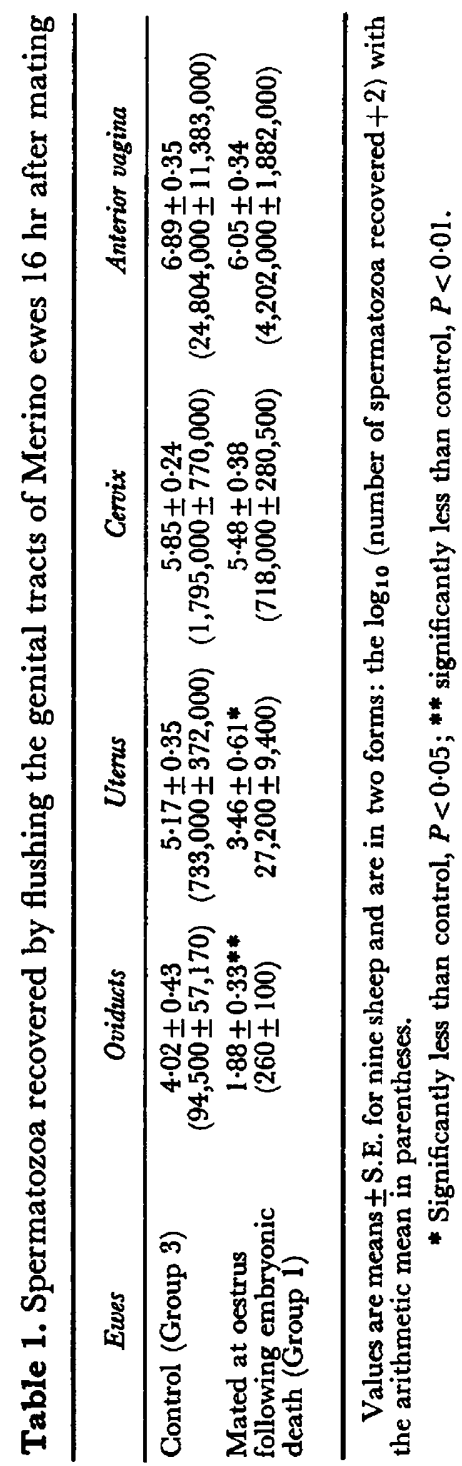


Killing embryos on Day 17 resulted in returns to service on Day $32 \cdot 1 \pm 1.83$ (S.E.) by the ewes in Group 1, and Day $29.4 \pm 1.59$ by those in Group 2. With the exception of one ewe in each of Groups 1 and 4, all ewes had a single CL at laparotomy.

\section{Sperm transport}

Spermatozoa were recovered from the anterior vagina and cervix of all ewes. In ewes whose embryos were killed (Group 1), however, spermatozoa were recovered from only seven of nine uteri and eleven of eighteen oviducts. Corresponding figures for the control ewes of Group 3 were nine out of nine uteri and seventeen out of eighteen oviducts, respectively. In Group 1, spermatozoa were recovered from one oviduct only in each of three ewes, and no spermatozoa were recovered from either oviduct in another two ewes. In one of these two ewes, no spermatozoa were recovered from the uterus.

Table 2. Spermatozoa remaining in the cervices of Merino ewes after flushing with $5 \mathrm{ml}$ saline

\begin{tabular}{|c|c|c|}
\hline \multirow{2}{*}{ Cervical segment } & \multicolumn{2}{|c|}{$\begin{array}{c}\text { Mean of } \\
\left.\log _{10} \text { (no. of spermatozoa/cm }+2\right)\end{array}$} \\
\hline & $\begin{array}{l}\text { Control ewes } \\
\text { (Group 3) }\end{array}$ & $\begin{array}{l}\text { Ewes mated at the } \\
\text { oestrus following } \\
\text { embryonic death } \\
\text { (Group 1) }\end{array}$ \\
\hline $\begin{array}{l}\text { Anterior } \\
\text { Middle } \\
\text { Posterior }\end{array}$ & $\begin{array}{l}4 \cdot 69 \\
5 \cdot 74 \\
5 \cdot 92\end{array}$ & $\begin{array}{l}5 \cdot 08 \\
5 \cdot 70 \\
5 \cdot 42\end{array}$ \\
\hline
\end{tabular}

Summary of the analyses of variance

\begin{tabular}{lrll}
\hline \multirow{2}{*}{ Source of variation } & d.f. & \multicolumn{2}{c}{ Variance ratios } \\
\cline { 3 - 4 } & & Control ewes & Treated ewes \\
\hline Distribution along cervix & 1 & $16.38^{* *}$ & 1.95 \\
$\quad$ Linear & 1 & $2 \cdot 77$ & 4.46 \\
Quadratic & 8 & 0.61 & $2.79^{*}$ \\
Differences between ewes & 16 & 0.4207 & 0.2671 \\
Residual mean square (error) & & & \\
\hline
\end{tabular}

$* P<0.05 ; \quad * * P<0.01$.

The mean \pm S.E. of the arithmetic values and the $\log _{10}$ values of the numbers of spermatozoa found in the lumen of the genital tracts are shown in Table 1. The ewes mated following embryonic death had significantly fewer spermatozoa in their oviducts and uteri.

Histological examination of the flushed cervices showed that there was a linear decrease in sperm density from the posterior to the anterior segments of the cervix in control sheep (Table 2). Distribution in the treated ewes was random.

$\log _{10}$ numbers of the total counts of spermatozoa in the cervices (i.e. 
Table 3. Correlations between the logarithm of the sperm counts from various regions of the reproductive tract of control ewes and ewes mated following embryonic death

\begin{tabular}{|c|c|c|c|c|}
\hline Region of tract & Ewes & $\begin{array}{c}\text { Correlation } \\
\text { coefficient }(\mathbf{r})\end{array}$ & $\begin{array}{c}\text { Regression } \\
\text { coefficient (b) }\end{array}$ & $\begin{array}{c}\text { Intercept } \\
\text { (a) }\end{array}$ \\
\hline Oviduct-uterus & $\begin{array}{l}\text { Control } \\
\text { Experimental }\end{array}$ & $\begin{array}{l}0.428 \\
0.295\end{array}$ & $\begin{array}{l}0.345 \\
0.554\end{array}$ & $\begin{array}{l}3 \cdot 783 \\
2 \cdot 413\end{array}$ \\
\hline $\begin{array}{l}\text { Oviduct-cervix } \\
\text { (periphery) }\end{array}$ & $\begin{array}{l}\text { Control } \\
\text { Experimental }\end{array}$ & $\begin{array}{c}0.634^{*} \\
-0.048\end{array}$ & $\begin{array}{r}0.142 \\
-0.024\end{array}$ & $\begin{array}{l}5 \cdot 932 \\
6 \cdot 356\end{array}$ \\
\hline $\begin{array}{l}\text { Oviduct-cervix } \\
\text { (wash) }\end{array}$ & $\begin{array}{l}\text { Control } \\
\text { Experimental }\end{array}$ & $\begin{array}{r}0.257 \\
-0.030\end{array}$ & $\begin{array}{r}0.144 \\
-0.027\end{array}$ & $\begin{array}{l}5 \cdot 278 \\
5 \cdot 533\end{array}$ \\
\hline Oviduct-vagina & $\begin{array}{l}\text { Control } \\
\text { Experimental }\end{array}$ & $\begin{array}{l}0.751 * * \\
0.030\end{array}$ & $\begin{array}{l}0.616 \\
0.030\end{array}$ & $\begin{array}{l}4 \cdot 416 \\
5 \cdot 995\end{array}$ \\
\hline $\begin{array}{l}\text { Uterus-cervix } \\
\text { (periphery) }\end{array}$ & $\begin{array}{l}\text { Control } \\
\text { Experimental }\end{array}$ & $\begin{array}{l}0 \cdot 509 \\
0.369\end{array}$ & $\begin{array}{l}0.141 \\
0.099\end{array}$ & $\begin{array}{l}5 \cdot 772 \\
5 \cdot 969\end{array}$ \\
\hline $\begin{array}{l}\text { Uterus-cervix } \\
\text { (wash) }\end{array}$ & $\begin{array}{l}\text { Control } \\
\text { Experimental }\end{array}$ & $\begin{array}{l}0.905^{* * * *} \\
0.577\end{array}$ & $\begin{array}{l}0.624 \\
0.272\end{array}$ & $\begin{array}{l}2 \cdot 625 \\
4 \cdot 541\end{array}$ \\
\hline Uterus-vagina & $\begin{array}{l}\text { Control } \\
\text { Experimental }\end{array}$ & $\begin{array}{c}0.699 * \\
-0.089\end{array}$ & $\begin{array}{r}0.709 \\
-0.049\end{array}$ & $\begin{array}{l}3 \cdot 222 \\
6 \cdot 221\end{array}$ \\
\hline $\begin{array}{l}\text { Cervix (periphery) } \\
\text {-cervix (wash) }\end{array}$ & $\begin{array}{l}\text { Control } \\
\text { Experimental }\end{array}$ & $\begin{array}{l}0.560 \\
0 \cdot 729^{*}\end{array}$ & $\begin{array}{l}1.400 \\
1.283\end{array}$ & $\begin{array}{l}-3 \cdot 256 \\
-2 \cdot 613\end{array}$ \\
\hline $\begin{array}{l}\text { Cervix (periphery) } \\
\text {-vagina }\end{array}$ & $\begin{array}{l}\text { Control } \\
\text { Experimental }\end{array}$ & $\begin{array}{l}0.649 * \\
0.607^{*}\end{array}$ & $\begin{array}{l}2 \cdot 385 \\
1 \cdot 240\end{array}$ & $\begin{array}{l}-8.614 \\
-1.772\end{array}$ \\
\hline $\begin{array}{l}\text { Cervix (wash) } \\
\text {-vagina }\end{array}$ & $\begin{array}{l}\text { Control } \\
\text { Experimental }\end{array}$ & $\begin{array}{l}0.627^{*} \\
0.673^{*}\end{array}$ & $\begin{array}{l}0.922 \\
0.781\end{array}$ & $\begin{array}{l}1.491 \\
1.770\end{array}$ \\
\hline
\end{tabular}

Prediction equation log $\mathrm{y}=a+b \log \mathrm{x}$.

$* P<0.05 ; * * P<0.01 ; * * * P<0.001$.

flushing plus histology) did not differ between control and treated ewes (6.65 $\pm 0 \cdot 11$ and $6 \cdot 41 \pm 0 \cdot 17$ respectively).

Correlations between sperm counts in the regions of the genital tract were evaluated (Table 3). The correlation coefficients between cervix and vagina were similar in the control and treated ewes, but the values for the correlations of oviduct and uterine numbers with other regions were higher for the control ewes.

\section{Uterine histology}

The data on the various uterine parameters studied are summarized in

Table 4. Height of the luminal epithelium, endometrium and circular muscle cross-sectional areas, and number of gland coils in the distal and proximal regions of the uterine horns of control ewes and ewes mated at the oestrus following embryonic death

\begin{tabular}{|c|c|c|c|c|c|}
\hline Ewe & $\begin{array}{l}\text { Uterine } \\
\text { region }\end{array}$ & $\begin{array}{l}\text { Height of } \\
\text { epithelium } \\
(\mu m)\end{array}$ & $\begin{array}{c}\text { Area of } \\
\text { endometrium } \\
\left(\mathrm{mm}^{2}\right)\end{array}$ & $\begin{array}{c}\text { Area of } \\
\text { circular } \\
\text { muscle }\left(m m^{2}\right)\end{array}$ & $\begin{array}{l}\text { No. of gland } \\
\text { coils }\end{array}$ \\
\hline Control & $\begin{array}{l}\text { Proximal } \\
\text { Distal }\end{array}$ & $\begin{array}{l}22 \cdot 7 \pm 1 \cdot 1^{a} \\
24 \cdot 0 \pm 1 \cdot 4^{a}\end{array}$ & $\begin{array}{l}48 \cdot 2 \pm 2 \cdot 8^{\mathrm{a}} \\
21 \cdot 2 \pm 2 \cdot 0^{\mathrm{b}}\end{array}$ & $\begin{array}{r}25.4 \pm 1.5^{\mathrm{a}} \\
9.7 \pm 0.7^{\mathrm{b}}\end{array}$ & $\begin{array}{l}2 \cdot 8 \pm 0 \cdot 2^{\mathrm{a}} \\
3 \cdot 1 \pm 0 \cdot 2^{\mathrm{a}}\end{array}$ \\
\hline $\begin{array}{l}\text { After embryonic } \\
\text { death }\end{array}$ & $\begin{array}{l}\text { Proximal } \\
\text { Distal }\end{array}$ & $\begin{array}{l}27 \cdot 5 \pm 1 \cdot 0^{\mathrm{b}} \\
28 \cdot 8 \pm 0 \cdot 9^{\mathrm{b}}\end{array}$ & $\begin{array}{l}47 \cdot 6 \pm 3 \cdot 5^{\mathrm{a}} \\
20 \cdot 3 \pm 1 \cdot 1^{\mathrm{b}}\end{array}$ & $\begin{array}{l}23 \cdot 7 \pm 1 \cdot 5^{\mathrm{a}} \\
10 \cdot 9 \pm 0.5^{\mathrm{b}}\end{array}$ & $\begin{array}{l}2 \cdot 7 \pm 0 \cdot 1^{\mathrm{a}} \\
3 \cdot 1 \pm 0 \cdot 2^{\mathrm{a}}\end{array}$ \\
\hline
\end{tabular}

Values are the means \pm S.E. for nine animals. Figures with different superscripts differ significantly $(P<0.01)$ from each other. 
Table 4. Preliminary analysis of the data revealed that in no case did the values for the right and left uterine horns differ significantly, and these have thus been pooled in the Table. The only significant treatment effect detected was that the height of the luminal epithelium was greater in the ewes receiving colchicine than in the controls. The cotyledons of ewes returning to service after embryonic death were relatively large and haemorrhagic compared to those of the controls, but attempts to quantify this effect by measurement of the limited number of cotyledons available in the small uterine samples collected were unsuccessful.

\section{DISCUSSION}

Earlier studies (Edey, 1972) indicated that in cyclic ewes, colchicine administered a mean of 14.7 days before mating had no detectable effect on fertility. This is supported by the normal fertility seen in Group 4 in which a mean of 12.4 days elapsed between colchicine administration and mating. The low fertility of the Group-2 ewes mated at the first cycle after colchicine-induced embryonic death (mean 29.4 days after colchicine treatment) is unlikely, therefore, to have been a side effect of colchicine.

The number of spermatozoa recovered from the tracts of the control ewes (Group 3) are compatible with the results of Mattner \& Braden (1967) who studied the tracts of Merino ewes $28 \mathrm{hr}$ after mating to two rams. Moreover, Lang \& Oh (1970) found that in Romney ewes the highest numbers of spermatozoa were recovered from all sections of the tract $16 \mathrm{hr}$ after mating. The results of the current experiment suggest that impaired sperm transport could account for the lowered fertility of ewes being mated for the first time following embryonic death.

The correlation coefficients show a positive relationship between sperm numbers in the cervix and vagina, with no effect of embryonic death. The positive correlations found between sperm counts in the oviduct or uterus and the cervix or vagina in control ewes confirms the dependence of counts in the cranial parts of the tract on sperm numbers in the caudal areas (Morton \& Glover, 1974). The caudal/cranial relationship was not seen in ewes after embryonic death had been induced and this emphasizes the impairment of normal forward movement of spermatozoa from the cervix in the treated ewes.

An abnormal uterine environment could reduce the numbers of spermatozoa in the uterus and oviducts. Although the only measured difference in the uteri was the greater height of the luminal epithelium at the first oestrus after embryonic death, the most striking visual difference was the enlarged and haemorrhagic caruncles, but these could not be successfully quantified. It appears that the uterus for some time after embryonic death retains some characteristics of pregnant ewes, one of which is increased capillary permeability (Boshier, 1970). The histological data cannot be compared with those of Bindon (1971) due to the sampling of different uterine sites.

Edey (1970) reported the presence of débris in some uteri on the day of the next ovulation after embryonic death, and again in the present study, two of the nine ewes in Group 1 showed a small residue. Large leucocyte populations occur in the uteri of such sheep (Thwaites, 1972) and phagocytes have been shown 
to ingest apparently normal spermatozoa (Bedford, 1965; Mattner, 1969). The spermatozoa could thus be engulfed while motile or after being killed by substances associated with the processes of embryo resorption and uterine involution. Although no attempt was made in the present study to differentiate between dead and live spermatozoa, the ones examined appeared normal.

In ruminants, the cervix may be regarded as acting as a sperm reservoir (Quinlan, Maré \& Roux, 1933; Mattner, 1963, 1968) and as a barrier to the progress of immotile spermatozoa (Mattner \& Braden, 1969). The observation that most of the spermatozoa in the cervix are not readily removed by flushing confirms the pattern of distribution reported by Mattner $(1966,1968)$.

The change in cervical function of the treated ewes shown by the absence of a linear decrease in resident sperm density could be related to the long period of exposure to progesterone occurring in ewes when their embryos were killed at Day 15 (Dooley, Wodzicka-Tomaszewska \& Edey, 1974). Alternatively, ewes which suffered colchicine-induced embryonic death may have experienced abnormal oestrogen levels which, in turn, may have adversely affected the build-up of spermatozoa in the cervix (Croker, Robinson \& Shelton, 1974).

In summary, our results suggest impairment of sperm transport as one of the causes of the lowered fertility following embryonic death. The findings emphasize the importance of the cervix in sperm transport.

\section{ACKNOWLEDGMENTS}

We are indebted to the Australian Research Grants Committee and the University of New England, for financial assistance.

\section{REFERENCES}

Abercrombie, M. (1946) Estimation of nuclear populations from microtome sections. Anat. Rec. 94, 239-247.

BEDFoRd, J. M. (1965) Effect of environment on phagocytosis of rabbit spermatozoa. F. Reprod. Fert. 9, 249-256.

Bindon, B. M. (1971) Systematic study of preimplantation stages of pregnancy in the sheep. Aust. $\mathcal{F}$. biol. Sci. 24, 131-147.

Boshrer, D. P. (1970) The pontamine blue reaction in pregnant sheep uteri. F. Reprod. Fert. 22, 595-596.

Croker, K. P., Robinson, T. J. \& Shelton, J. N. (1974) The transport of spermatozoa in ewes treated with steroid hormones. F. Reprod. Fert. 36, 461-462.

Dooley, M., Wodzicka-Tomaszewska, M. \& EdEy, T. N. (1974) Luteal function following embryonic mortality in ewes. F. Reprod. Fert. 36, 462.

EDEY, T. N. (1967) Early embryonic death and subsequent cycle length in the ewe. J. Reprod. Fert. $13,437-443$.

EDEY, T. N. (1970) Nutritional stress and pre-implantation mortality in Merino sheep (1964-67). General discussion and conclusions. F. agric. Sci., Camb. 74, 199-204.

EDEY, T. N. (1972) Fertility at the first oestrus following embryonic death. F. Reprod. Fert. 28, 147-148.

Lamond, D. R. (1963) Diagnosis of early pregnancy in the ewe. Aust. vet. 7. 39, 192-195.

LANG, D. R. \& OH, Y. K. (1970) Distribution of spermatozoa in the reproductive tract of the Romney ewe. N.Z. F. agric. Res. 13, 157-166.

Mattner, P. E. (1963) Spermatozoa in the genital tract of the ewe. II. Distribution after coitus. Aust. J. biol. Sci. 16, 688-694.

MatTneR, P. E. (1966) Formation and retention of the spermatozoan reservoir in the cervix of the ruminant. Nature, Lond. 212, 1479-80.

MatTNER, P. E. (1968) The distribution of spermatozoa and leucocytes in the female genital tract in goats and cattle. $\mathcal{F}$. Reprod. Fert. 17, 253-261.

Mattner, P. E. (1969) Phagocytosis of spermatozoa by leucocytes in bovine cervical mucus in vitro. 7. Reprod. Fert. 20, 133-134. 
Mattner, P. E. \& Braden, A. W. H. (1967) Studies in flock mating of sheep. 2. Fertilization and prenatal mortality. Aust. 7. exp. Agric. Anim. Husb. 7, 110-116.

Matrner, P. E. \& BRAden, A. W. H. (1969) Comparison of the distribution of motile and immotile spermatozoa in the ovine cervix. Aust. 7. biol. Sci. 22, 1069-1070.

Morton, D. B. \& Glover, T. D. (1974) Sperm transport in the female rabbit: the rôle of the cervix. 7. Reprod. Fert. 38, 131-138.

Murdoch, B. E. \& O'SheA, T. (1973) Effect of storage of rabbit spermatozoa at $-79^{\circ} \mathrm{C}$ on their subsequent transport and fertility in the rabbit doe. Aust. F. biol. Sci. 26, 645-651.

Quinlan, J., Maré, G. S. \& Roux, L. L. (1933) A study of the duration of motility of spermatozoa in the different divisions of the reproductive tract of the Merino ewe. Onderstepoort $\mathcal{F}$. vet. Sci. Anim. Ind. 1, 135-145.

Thwarres, C. J. (1972) The time course of embryonic resorption in the ewe. Aust. F. biol. Sci. 25, 597603. 